\title{
Goldenhar syndrome: rare case reported from secondary health care facility in Himachal Pradesh
}

\author{
Dharmani A. ${ }^{1}$, Sharma V. ${ }^{2}$, Thakur S. ${ }^{3}$, Kashyap S. ${ }^{4}$ \\ DOI: https://doi.org/10.17511/ijpr.2020.i01.08 \\ ${ }^{1}$ Ankur Dharmani, MD Pediatrics, (PGIMER Chandigarh), Regional Hospital, Bilaspur, Himachal Pradesh, India. \\ 2 Vandna Sharma, MS Ophthalmology (Dr RPGMC TANDA), Regional Hospital, Bilaspur, Himachal Pradesh, India. \\ 3 Swati Thakur, MD Radiodiagnosis (AIIMS New Delhi), Phoenix Diagnostic Center, Bilaspur, Himachal Pradesh, India. \\ ${ }^{4}$ Sonia Kashyap, MD Internal Medicine (PGIMER Chandigarh), DDU Hospital, Shimla, Himachal Pradesh, India.
}

Dr. Maurice Goldenhar, a renowned Swiss ophthalmologist classified the clinical features and named the malformation complex as Goldenhar Syndrome and described it as a congenital defect characterized by constellation of malformations classically involving the face, eyes and ears. Principal deformities of the Goldenhar syndrome are often combined with various malformations, like Cleft lip and/or palate, tongue cleft, unilateral tongue hypoplasia, and parotid gland aplasia, Rib anomalies, Congenital heart disease (ventricular septal defects). A 12-year-old female patient diagnosed with Goldenhar syndrome at secondary care Regional Hospital Bilaspur, Himachal Pradesh. She was diagnosed with a case of Goldenhar syndrome on clinic-radiological investigations. The patient reported to ophthalmology OPD of the hospital with the chief complaint of soft tissue structure in left eye with decreased vision. On examination limbal dermoid was observed. Patient was having pre-auricular tissue tag on both sides, hemifacial micrognathia and microstomia. Correlating the history and physical findings a provisional diagnosis of Goldenhar Syndrome was made with differential diagnosis of Franschetti syndrome or Treacher - Collins syndrome, Nager syndrome or acro-facial dysostosis and Townes-Brocks syndrome. Based on the clinical and radiographic findings a diagnosis of Goldenhar syndrome was made. Severe cases of GS can affect the routine and social life of the patient. Early detection can help avoid complications at a later stage of life. Such patients will have an increased risk for psychosocial difficulties. The study of this condition is still controversial because the symptoms and the physical features may vary greatly in range and severity from case to case.

Keywords: Goldenhar syndrome, Oculo-auriculo-vertebral (OAV) dysplasia, Congenital defects

\section{Corresponding Author}

Sonia Kashyap, Internal Medicine (PGIMER Chandigarh), DDU Hospital, Shimla, Himachal Pradesh, India.

Email: dr.sonia21@gmail.com
How to Cite this Article

To Browse

Dharmani A, Sharma V, Thakur S, Kashyap S. Goldenhar syndrome: rare case reported from secondary health care facility in Himachal Pradesh. Pediatric Rev Int J Pediatr Res. 2020;7(1):42-48. Available From https://pediatrics.medresearch.in/index.php/ijpr/arti cle/view/567

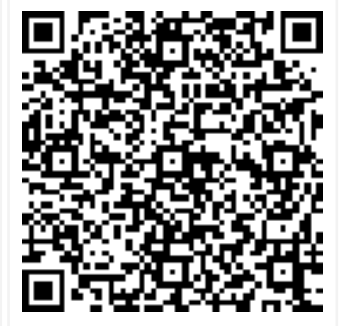
2019-12-26

Conflict of Interest No

Review Round 1
2019-01-07
Funding
Nil

Review Round 1 $\mathrm{Nil}$

Review Round 2
2019-01-12
Ethical Approval
Yes

Review Round 2 Yes
Review Round 3

Plagiarism X-checker $7 \%$
Accepted 2019-01-17

Note

(c) 2020 by Ankur Dharmani, Vandna Sharma, Swati Thakur, Sonia Kashyap and Published by Siddharth Health Research and Social Welfare Society. This is an Open Access article licensed under a Creative Commons Attribution 4.0 International License ttps://creativecommons.org/licenses/by/4.0/ unported [CC BY 4.0]. 


\section{Introduction}

Goldenhar syndrome (GS) is also known as oculoauriculo-vertebral (OAV) dysplasia. It is considered a variant of hemifacial macrosomia [1]. In 1881, the first observation of oculo-auriculo-vertebral (OAV) dysplasia was reported by Von Arlt and in 1952, Dr. Maurice Goldenhar, a renowned Swiss ophthalmologist classified the clinical features and named the malformation complex as Goldenhar Syndrome and described it as a congenital defect characterized by constellation of malformations classically involving the face, eyes and ears [2,3].

Reported incidence of this syndrome is $1: 3500$ to $1: 5600$ with a male to female ratio of $3: 2$ [4]. Although most cases are sporadic, autosomal dominance inheritance has also been described. Though, the aetiology of Goldenhar syndrome is not well established, it is thought to be due to exposure to various viruses or chemicals during pregnancy. Some researchers also suggested gestational diabetes mellitus as one of the causes. The MSX homeobox genes play a crucial role in the pathogenesis $[5,6]$.

Other clinical features include limbal dermoid or lipo-dermoid, Preauricular skin tags, Unilateral facial hypoplasia, Neck: Branchial cartilage, branchial fistula, webbing, short neck, abnormalities of sternocleidomastoid muscle. Unilateral macrostomia (lateral facial cleft). Back: Pilonidal dimple, kyphoscoliosis, Sprengel's deformity, Hands / Fingers: clubbing, polydactyly, clinodactyly, single palmar crease, and Vertebral column anomalies (atlas occipitalization, synostosis, hemivertebrae, fused vertebrae, scoliosis, and bifid spine) [7].

The multifactorial etiopathogenesis includes nutritional and environmental factors that result in blastogenesis disorders. Information to identify these etiological factors do not exist [8]. The anomalies of 1 st and 2 nd branchial arcs have been observed in children born from mothers who were exposed to thalidomide, primidone and retinoic acid, in addition to diabetic mothers $[9,10]$. Embryologically, the ocular-auricle-vertebral defect has been considered an anomaly of 1 st branchial arc, but this alteration does not explain the anomalies in the brain, heart, kidneys or dorsal spine [11].

Principal deformities of the Goldenhar syndrome are often combined with various malformations, like
Cleft lip and/or palate, tongue cleft, unilateral tongue hypoplasia, and parotid gland aplasia, Rib anomalies, Congenital heart disease (ventricular septal defects), anomalies of the urogenital and gastrointestinal system, mental retardation, Venous anomalies, associated juvenile glaucoma in Turner's syndrome, Congenital Facial nerve palsy and Growth hormone deficiency [7].

\section{Case Report}

A 12-year-old female patient diagnosed with Goldenhar syndrome at secondary care Regional Hospital Bilaspur, Himachal Pradesh. She was diagnosed with a case of Goldenhar syndrome on clinic-radiological investigations.

The patient reported to ophthalmology OPD of the hospital with the chief complaint of soft tissue structure in left eye with decreased vision. On examination limbal dermoid was observed. With a syndromic suspicion, patient was referred to Pediatrics department for further clinical examination.

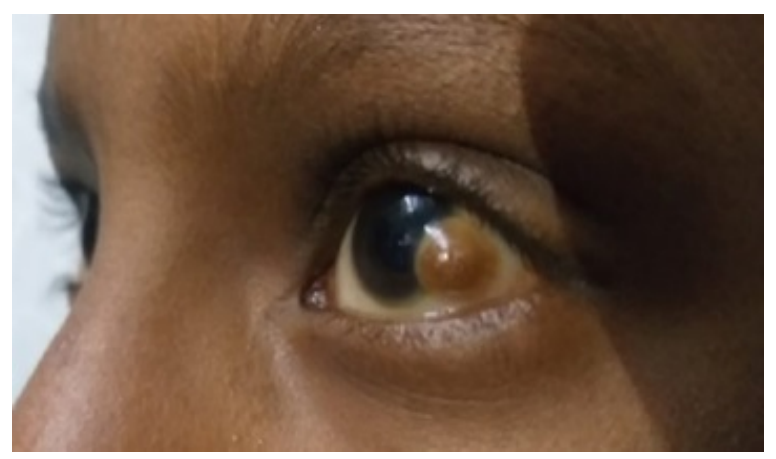

Fig-1: Image showing limbal dermoid

On physical examination in pediatrics department, it was found that the patient was having pre-auricular tissue tag on both sides, hemifacial micrognathia and microstomia

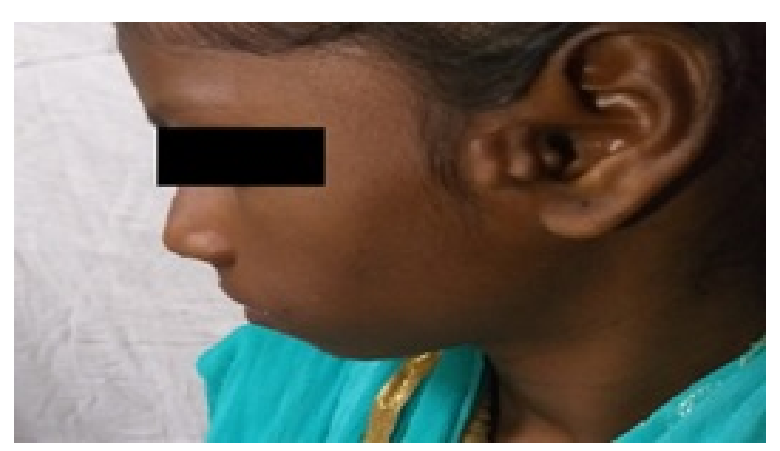




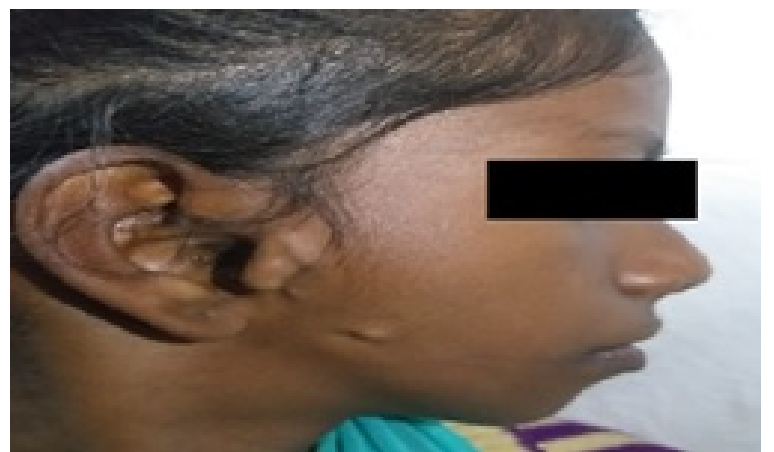

Fig-2: Image showing tissue tags pre-auricular tissue tags and blind fistula on right side

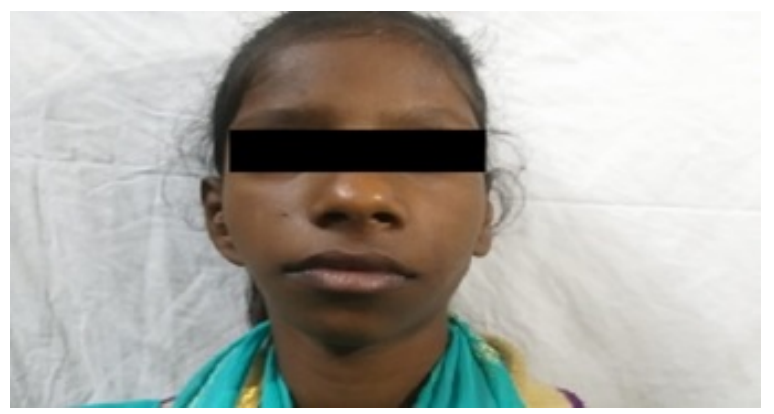

Fig 3: Image showing mandibular hypoplasia

There was no family history of any genetic abnormality or infections. The parents were healthy and their marriage was non-consanguineous. Correlating the history and physical findings a provisional diagnosis of Goldenhar Syndrome was made with differential diagnosis of Franschetti syndrome or Treacher - Collins syndrome, Nager syndrome or acro-facial dysostosis and TownesBrocks syndrome. On investigations patient was showing normal ECHO, USG Abdomen \& KUB, audiometry \& blood investigation while there was refractive error with astigmatism.

On NCCT face with screening whole spine with 3D construction, following observations were made:

- Right sided mandible is hypoplastic predominantly in region of ramus as well as mandibular condyle.

- Mandibular condyle is located anteromedially compared to left side and shows ill formed temporomandibular joint.

- Bilateral preauricular tags and blind fistula in front of preauricular tag on one side.

- Screening spine with intervertebral discs showing grossly normal study.

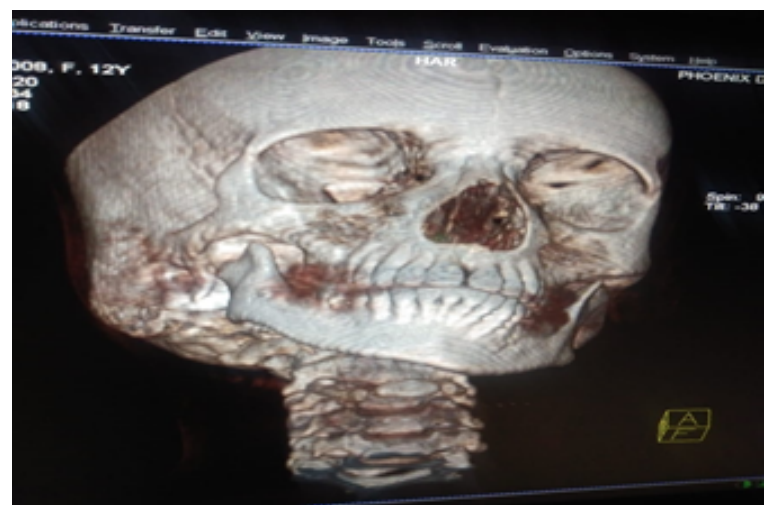

A)

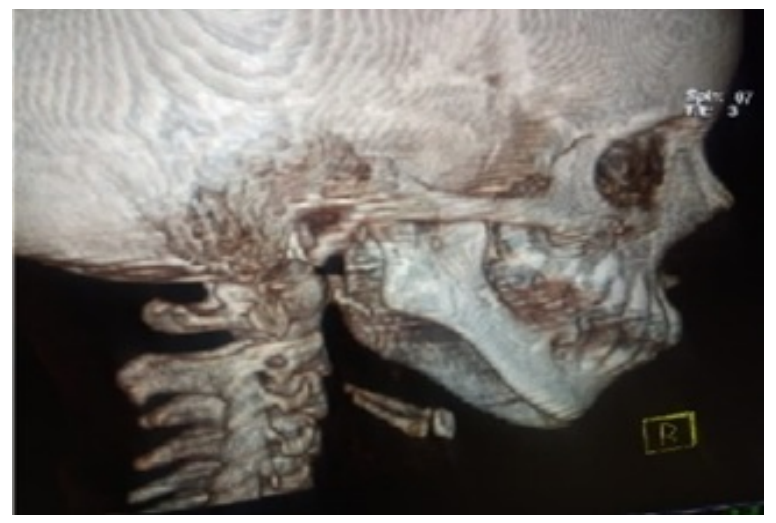

B)

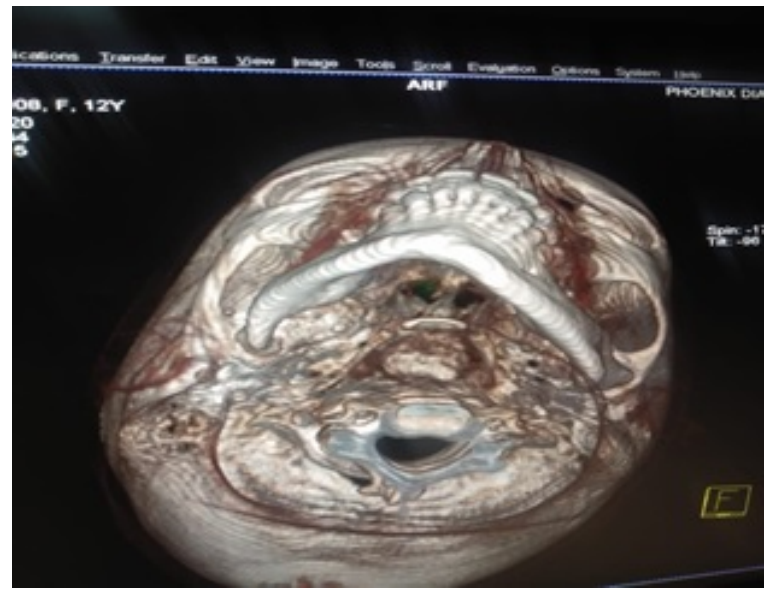

(C)

Fig-4: A, B and C Showing right hypoplastic mandible in the region of ramus and condylar area with anteromedial location of mandibular condyle ill formed temporomandibular joint

Based on the clinical and radiographic findings a diagnosis of Goldenhar syndrome was made. The genetic analysis was planned but couldn't be done due to affordability issues to the family. 
(All other blood investigations are done at regional hospital Bilaspur free of cost under RBSK scheme and radiological investigations were done free of cost). The patient was referred to tertiary care hospital for multidisciplinary management.

\section{Discussion}

A number of case reports of Goldenhar syndrome have been described in literature. In 1997, Araneta et al. described the occurrence of Goldenhar syndrome among children of Persian Gulf War veterans and found that 7 infants out of an estimated 75,414 infants had Goldenhar syndrome [12]. As similar to previously reported cases, our patient had marked right facial hypoplasia

Tsai and Tsai reported a family in which seven members in three successive generations were diagnosed with Goldenhar syndrome [13]. Clinical features in all were highly suggestive of Goldenhar syndrome [7]. Anderson and David reported spinal anomaly in seven patients with wide range of abnormalities including butterfly vertebrae, hemivertebrae, kyphosis and rib anomalies [14]. Ozdemir et al. reported a case of 12-year-old male with postaxial polydactyly, congenital heart disease, vertebral anomaly and facial asymmetry [15]. Berker, Acaroglu, and Soykan reported a patient with congenital facial nerve paralysis in conjunction with Goldenhar syndrome [16]. Kumar et al. reported polydactyly and hydrocephalus as rare associations with Goldenhar syndrome [17]. Zakaur-Rab and Mittal reported a case where drusen of the optic nerve head was found in association with this syndrome [18].

Our patient was provisionally diagnosed as Goldenhar syndrome but a number of other first and second arch syndromes were considered in the differential diagnosis [19]. A recent study detected multiple congenital anomalies in ecography findings in 20 cases. The gestational age in the diagnosis varied from 15 to 35 weeks and in more than half of the cases it was associated to the polyhydramnios or oligohydramnios. The characteristics observed were: face malformations present in $52 \%$ of the cases, as microphtalmy, auricular abnormalities, face asymmetry and face cleft; amongst the neurological alterations, occiptal encephalocele, hydrocephaly and cerebellar hypoplasia were observed, which occurred in $47 \%$ of the findings; cardiac defects, radial aplasia and renal agenesia were seen less frequently $[20,21]$.
Table-1: Differential diagnosis of Goldenhar Syndrome

\begin{tabular}{|c|c|}
\hline Differential diagnosis & Classical presentation \\
\hline $\begin{array}{l}\text { Our Index Case i.e. } \\
\text { Goldenhar Syndrome }\end{array}$ & $\begin{array}{l}\text { Hemifacial microsmia } \\
\text { Mandibular hypoplasia } \\
\text { Micrognathia } \\
\text { Preauricular appendages/tags with blind fistula on } \\
\text { one side } \\
\text { Limbal dermoid } \\
\text { Multifactorial inheritance with variable } \\
\text { penetrance/Heterogeneity }\end{array}$ \\
\hline Goldenhar syndrome & $\begin{array}{l}\text { unilateral cleft lip or palate is associated with } \\
\text { other facial anomalies such as Facial asymmetry } \\
\text { Asymmetric malformation of 1st and 2nd branchial } \\
\text { arch } \\
\text { Unilateral orbital anomalies } \\
\text { Ear abnormalities: with appendix or pre-auricular } \\
\text { tag (common sign) } \\
\text { Retrognathia / micrognathia (common sign) }\end{array}$ \\
\hline $\begin{array}{l}\text { Treacher - Collins } \\
\text { Syndrome: }\end{array}$ & $\begin{array}{l}\text { Symmetrical deformity of the face: } \\
\text { Cleft palate } \\
\text { Symmetrical malar and mandibular hypoplasia but } \\
\text { without agnathia } \\
\text { Severe micrognathia } \\
\text { Abnormal auricles/External ear } \\
\text { deformities/Microtia } \\
\text { Coloboma of lower eyelid with deficient eyelashes } \\
\text { Disruption of scalp hair in the preauricular region } \\
\text { (Sideburn) } \\
\text { Bilateral malformation of } 1 \text { st and } 2 \text { nd branchial } \\
\text { arch } \\
\text { AD inheritance (mostly) }\end{array}$ \\
\hline $\begin{array}{l}\text { Nager syndrome OR } \\
\text { Preaxial acro-facial } \\
\text { dysostosis: }\end{array}$ & $\begin{array}{l}\text { Pre axial limb anomalies like: } \\
\text { (Hypoplasia or absence of radius, hypoplasia or } \\
\text { absent thumbs, triphalangeal thumbs, radioulnar } \\
\text { synostosis) } \\
\text { Facial anomalies like: } \\
\text { (Malar hypoplasia with downward slanting } \\
\text { palpebral fissures, lower eyelid coloboma, severe } \\
\text { micrognathia) } \\
\text { AD or AR inheritance }\end{array}$ \\
\hline $\begin{array}{l}\text { Townes-Brocks } \\
\text { syndrome: }\end{array}$ & $\begin{array}{l}\text { Lop ears/Dysplastic ears } \\
\text { Imperforate anus } \\
\text { Sensorineural and/or conductive hearing loss } \\
\text { Thumb malformations } \\
\text { (triphalangeal/duplication/hypoplastic thumb) } \\
\text { AD inheritance }\end{array}$ \\
\hline
\end{tabular}

Preauricular tags can be associated with several genetic conditions such as: Oculoauriculovertebral dysplasia, Chromosome arm 11q duplication syndrome, Chromosome arm $4 p$ deletion syndrome and Chromosome arm $5 p$ deletion syndrome but our case doesn't have classical findings of these 
Syndromes and fit only in Goldenhar syndrome phenotype.

Both laboratorial and image tests are important for the diagnosis, once they are directly related to provoked alterations. The X-ray of the zigomatic bones shows a macroscopic deficiency of bone symmetry development. Also a possibility of agenesia of these bones exists, with defect of fusing of the zigomatic arc and agenesia of the palatine bones. Palatine cleft must radiographically be observed. Ophthalmological and otorhinolaryngological examinations are also important for the final diagnosis [22].

\section{Table-2: Comparatives studies}

\begin{tabular}{|c|c|c|}
\hline $\begin{array}{l}\text { Name } \\
\text { of the } \\
\text { authors }\end{array}$ & $\begin{array}{l}\text { Year } \\
\text { of the } \\
\text { study }\end{array}$ & Clinical Features \\
\hline $\begin{array}{l}\text { Our } \\
\text { index } \\
\text { case }\end{array}$ & 2020 & $\begin{array}{l}\text { Limbal dermoid, Preauricular skin tags, Unilateral facial } \\
\text { hypoplasia, Blind fistula in front of preauricular tag on one } \\
\text { side. }\end{array}$ \\
\hline $\begin{array}{l}\text { Vasudev } \\
\text { et al } \\
{[23]}\end{array}$ & 2005 & $\begin{array}{l}\text { Reported a case with juvenile glaucoma in Turner's } \\
\text { syndrome, along with loss of vision in one eye, } \\
\text { preauricular appendages, absence of uterus and right } \\
\text { kidney, }\end{array}$ \\
\hline $\begin{array}{l}\text { Sharma } \\
\text { et al [6] }\end{array}$ & 2006 & $\begin{array}{l}\text { Reported a patient with polydactyly hand, facial } \\
\text { asymmetry; hypoplastic maxilla, LMN facial palsy, } \\
\text { dysmorphic ear, slightly narrowed EAC, conductive } \\
\text { hearing loss ear, short neck, shortened } \\
\text { sternocleidomastoid, divarication of recti, Pilonidal dimple. } \\
\text { Macrostomia was present. There was elevation of scapula } \\
\text { and mild scoliosis. Presence of epicanthal folds and } \\
\text { microphthalmia. }\end{array}$ \\
\hline $\begin{array}{l}\text { Mahore } \\
\text { et al [5] }\end{array}$ & 2010 & $\begin{array}{l}\text { Lower motor neuron facial nerve paresis, bilateral } \\
\text { microtia, inferiorly situated ears, torticollis, left hemifacial } \\
\text { hypoplasia. Ectopic kidneys, }\end{array}$ \\
\hline
\end{tabular}

Stringer et al [24]. reported portal vein cavernoma in association with Goldenhar syndrome. They presented 3 cases with Goldenhar syndrome and portal vein cavernoma. Maan and others [25] reported a case of two siblings with Goldenhar syndrome. They presented with clinical features suggestive of Goldenhar syndrome with no systemic abnormality. Gajre et al [26] reported Goldenhar in association with agenesis of septum pellucidum. Vinay and others [4] reported Goldenhar syndrome based on clinical and radiographic findings with no systemic involvement.

\section{Conclusion}

Severe cases of GS can affect the routine and social life of the patient.
Early detection can help avoid complications at a later stage of life. Such patients will have an increased risk for psychosocial difficulties. The study of this condition is still controversial because the symptoms and the physical features may vary greatly in range and severity from case to case.

Declaration of patient consent: The authors certify that they have obtained all appropriate patient consent forms. In the form the patient(s) has/have given his/her/their consent for his/her/their images and other clinical information to be reported in the journal. The patients understand that their names and initials will not be published, and due efforts will be made to conceal their identity, but anonymity cannot be guaranteed.

\section{Acknowledgement}

Authors would like thank Dr. Swati Thakur proprietor Phoenix Diagnostic Centre for providing free radiological/sonographic/Echo investigations.

\section{Reference}

01. Martelli H Jr, Miranda RT, Fernandes CM, Bonan PR, Paranaíba LM, Graner E, et al. Goldenhar syndrome- Clinical features with orofacial emphasis. J Appl Oral Sci. 2010;18(6)646-649. doi: 10.1590/s1678-77572010000600019 [Crossref] [PubMed][Google Scholar]

02. Von Arlt F. Clinical presentation of diseases of the eye. 1st ed, Vienna- Braumuller publications. 1881. [Crossref][PubMed][Google Scholar]

03. Goldenhar M. Associated malformations of eye and ear, particularly dermoid syndrome epibulbarappendices, congenital auricular fistulas and its relations with Manibulofacial Dysostosis. J Genet Hum. 1952;1;243-282. [Crossref][PubMed][Google Scholar]

04. Vinay C, Reddy R S, Uloopi K S, Madhuri V, Sekhar R C. Craniofacial features in Goldenhar syndrome. J Indian Soc Pedod Prev Dent. 2009;27(2)121-124. doi: 10.4103/09704388.55339 [Crossref][PubMed][Google Scholar]

05. Mahore A, Dange N, Nama S, Goel A. Facioauriculo-vertebro-cephalic spectrum of Goldenhar syndrome. Neurol India. 2010;58(1)141-4. doi: 10.4103/0028-3886.60409 [Crossref][PubMed] [Google Scholar] 
06. Sharma JK, Pippal SK, Raghuvanshi SK, Shitij A. Goldenhar-Gorlin's syndrome- A case report. Indian J Otolaryngol Head Neck Surg. 2006;58(1)97-101. doi: 10.1007/BF02907757 [Crossref][PubMed] [Google Scholar]

07. Kokavec R. Goldenhar syndrome with various clinical manifestations. Cleft Palate Craniofac J. 2006;43(5)628-634. doi: 10.1597/05-094 [Crossref][PubMed][Google Scholar]

08. Lessick $M$, Vasa $R$, Israel J. Severe manifestations of oculoauriculovertebral spectrum in a cocaine exposed infant. J Med Genet. 1991;28(11)803-804. doi: 10.1136/jmg.28.11.803 [Crossref][PubMed][Google Scholar]

09. Gorlin RJ, Cohen MM, Levin LS. Branchial arch and oroacral disorders, In- Syndromes of the head and neck. 3ed, New York- Oxford University Press. 641-8. [Crossref][PubMed][Google Scholar]

10. Johnson KA, Fairhust J, Clarke NM. Oculoauriculovertebral spectrum- new manifestations. Pediatr Radiol. 1995;25(6)446-448. doi: $\quad 10.1007 /$ bf02019062 [Crossref][PubMed] [Google Scholar]

11. Regenbogen L, Godel V, Goya V, Godman RM. Further evidence for an autosomal dominant form of oculoauriculovertebral dysplasia. Clin Genet. 1982;21(3)161-167. doi: 10.1111/j.13990004.1982.tb00957.x [Crossref][PubMed][Google Scholar]

12. Araneta MR, Moore CA, Olney RS, Edmonds LD, Karcher JA et al. Goldenhar syndrome among infants born in military hospitals to Gulf War veterans. Teratol. 1997;56(4)244-251. doi: 10.1002/(sici)1096-

9926(199710)56:4\%3C244: :aid-tera3\%3E3.3.co;2y [Crossref][PubMed][Google Scholar]

13. Tsai FJ, Tsai $\mathrm{CH}$. Autosomal dominant inherited oculo-auriculo-vertebral spectrum- report of one family. Zhonghua Min Guo Xiao Er Ke Yi Xue Hui Za Zhi. 1993;34(1)27-31;14. Anderson PJ, David DJ. Spinal anomalies in Goldenhar syndrome. Cleft Palate Craniofac J. 2005;42(5)477-480. doi: 10.1597/04-142051r.1 [Crossref][PubMed][Google Scholar]

14. Ozdemir O, Arda K, Turhan $\mathrm{H}$, Tosun $\mathrm{O}$. Goldenhar's Syndrome. Asian Cardiovasc Thorac Ann. 2002;10(3)267-269. doi: $10.1177 / 021849230201000320$ [Crossref][PubMed] [Google Scholar]
15. Berker N, Acaroğlu G, Soykan E. Goldenhar's Syndrome (oculoauriculo-vertebral dysplasia) with congenital facial nerve palsy. Yonsei Med J. $2004 ; 29 ; 45(1) 157-160$. 10.3349/ymj.2004.45.1.157 [Google Scholar]

doi:

16. Kumar R, Balani B, Patwari AK, Anand VK, Ahuja B. Goldenhar syndrome with rare associations. Indian J Pediatr. 2000;67(3)231-233. doi: 10.1007/bf02723669 [Crossref][PubMed][Google Scholar]

17. Zaka-ur-Rab Z, Mittal S. Optic Nerve Head Drusen in Goldenhar Syndrome. JK Science. 2007;9;33-34. [Crossref][PubMed][Google Scholar]

18. Narayanan HS, Mohan KS, Manjunatha KR, Channabasavanna SM. An unusual variant of hallermann - streiff syndrome. Indian J Psychiatry. 1985;27(2)159-162. [Crossref][PubMed][Google Scholar]

19. Verona LL, Damian NG, Pavarina LP, Ferreira CHF, Melo DG. Monozygotic twins discordant for Goldenhar syndrome. J Pediatr (Rio J). 2006;82(1)75-78. doi: 10.2223/JPED.1441 [Crossref][PubMed][Google Scholar]

20. Castori $M$, Brancati $F$, Rinaldi $R$, Adami $L$, Mingarelli R, Grammatico $P$, et al. Antenatal presentation of the oculo-auriculo-vertebral spectrum (OAVS). Am J Med Genet Part A. 2006;140A(14)1573-1579. doi: 10.1002/ajmg.a.31290 [Crossref][PubMed][Google Scholar]

21. Schaffer AJ, Hine MK, Levy BM. Tratado de patologia bucal. 4th ed, Rio de JaneiroInteramericana. 1985;631. [Crossref][PubMed] [Google Scholar]

22. Rao VA, Kaliaperumal S, Subramanyan T, Rao $K R$, Bhargavan R. Goldenhar's sequence with associated juvenile glaucoma in Turner's syndrome. Indian J Ophthalmol. 2005;53(4)267-8. doi: 10.4103/0301-4738.18909 [Crossref][PubMed] [Google Scholar]

23. Stringer MD, Tovar JA, McKiernan PJ, Tanner S. Portal vein cavernoma associated with Goldenhar syndrome. J Pediatr Gastroenterol Nutr. 2005;41(3)368-370. doi: 10.1097/01.mpg.0000174333.85463.4f [Crossref] [PubMed][Google Scholar] 
24. Maan MA, Saeed G, Akhtar SJ, Iqbal J. Goldenhar syndrome- case reports with review of literature. JPAD. 2008;18;53-55. [Crossref] [PubMed][Google Scholar]
25. Gajre M, Palaniswamy K, Rathi S, Rathod D, Deshpande V, Agrawal M. Goldenhar Syndrome with Agenesis of Septum Pellucidum. Bombay Hosp J. 2008;50(4)687-688. [Crossref][PubMed][Google Scholar] 